\title{
CASE-BASED REASONING UNTUK APLIKASI PEMILIHAN PESTISIDA HAMA PADI BERBASIS WEB
}

\author{
Abdul Mubarak ${ }^{1}$, Abdul Muis ${ }^{2}$ \\ ${ }^{1}$ Program Studi Teknik Informatika, Fakultas Teknik, Universitas Khairun Ternate \\ ${ }^{2}$ Program Studi Teknim Informatika, Fakultas Ilmu Komputer, Universitas Indonesia Timur Makassar \\ E-mail: $\underline{1}$ abdulmubarak029@gmail.com, ${ }^{2}$ abdulmuis.160674@gmail.com
}

(Naskah masuk: 20 Juli 2020, diterima untuk diterbitkan: 6 Agustus 2020)

\begin{abstract}
Abstrak
Padi merupakan tanaman yang menjadi komoditi unggulan di Indonnesia dikarenakan beras menjadi bahan makanan pokok bagi masyarakat Indonesia dan asia. Salah satu masalah yang dihadapi oleh petani terkait dengan perubahan cuaca sehingga hama dapat menyerang padi. Dengan demikian tentu petani membutuhkan pestisida hama tanaman padi. Namun pemilihan pestisida terkadang kurang tepat sehingga berpengaruh pada hasil panen. Untuk itu perlu ada solusi untuk dapat memecahkan permasalahan dalam pemilihan pestisida. Salah satu caranya dengan memanfaatkan data-data lama untuk merekomendasikan pestisida yang baik. Penelitian ini bertujuan untuk implementasi algoritma Case Based Reasoning (CBR) pada aplikasi pemilihan pestisida hama padi menggunakan bahasa pemrograman berbasis web. Penelitian ini menggunakan metode experimental, dimana akan dilakukan pengujian algoritma Case Based Reasoning terhadap kasus pemilihan pestisida hama tanaman padi. Penelitian ini menghasilkan sebuah aplikasi yang dapat menyediakan informasi tentang hama yang menyerang tanaman padi dan informasi tentang pestisida yang dapat digunakan oleh user. Aplikasi ini juga telah diuji dengan black box testing dan hasilnya telah berjalan sesuai.
\end{abstract}

Kata kunci : Case Based Reasoning, Hama, Padi, Aplikasi web.

\section{CASE-BASED REASONING FOR WEB BASED SELECTION OF RICE PESTICIDES}

\begin{abstract}
Rice is a superior commodity in Indonesia because rice is a staple food for the people of Indonesia and Asia. One of the problems faced by farmers is related to weather changes so that pests can attack rice. Thus, naturally farmers need rice pesticides. However, the selection of pesticides is sometimes not right so it affects the yields. For this reason, there needs to be a solution to be able to solve problems in the selection of pesticides. One way is to use old data to recommend good pesticides. This research aims to implement the Case Based Reasoning (CBR) algorithm on the application of rice pesticide selection using a web-based programming language. This study uses an experimental method, which will test the Case Based Reasoning algorithm for cases of pesticide selection for rice plants. This research resulted in an application that can provide information about pests that attack rice plants and information about pesticides that can be used by users. This application has also been tested with black box testing and the results have gone accordingly.
\end{abstract}

Keyword : Case Based Reasoning, Pests, Rice, Application web.

\section{PENDAHULUAN}

Padi merupakan tanaman yang menjadi komoditi unggulan di Indonnesia dikarenakan beras menjadi bahan makanan pokok bagi masyarakat Indonesia. Masyarakat Indonesia menjadikan nasi sebagai bahan untuk memenuhi kebutuhan kalori harian [1]. Tak hanya di Indonesia hampir masyarakat di ASEAN menjadikan beras sebagai makanan pokok mereka.

Perubahan cuaca yang sering terjadi mengakibatkan terjadinya dampak yang kurang baik terhadap tanaman padi. Perubahan tersebut menyebabkan terganggunya tanaman padi akibat adanya hama yang menyerang tanaman, diantaranya yaitu, wereng, ulat, tungau walang sangit, dan tikus. Namun hama tersebut dapat dikendalikan secara kimiawi melalui penggunaan pestisida [2].

Pemilihan pestisida dilakukan petani dengan memilih pestisida yang banyak tersedia dipasaran, namun pemilihan pestisida terkadang masih kurang tepat yang berdampak pada tidak maksimalnya hasil panen [3]. 
Menurut [4], Pestisida dapat berupa semua jenis zat kimia atau berupa mikro organisme yang sudah mati maupun virus yang dapat digunakan untuk menghilangkan, mengusir serta membebaskan tanaman dari berbagai penyakit termasuk hama.

Case-Based Reasoning (CBR) mulai banyak dikenal diberbagai bidang teknologi informasi dan ilmu komputer. Case-Based Reasoning (CBR) menjadi salah satu model pendekatan untuk pemecahan masalah yang bekerja dengan cara menghitung tingkat kemiripan antara masalah yang pernah terjadi sebelumnya dengan masalah yang baru [5]. Case-Based Reasoning ini akhirnya menjadi suatu cara pandang pemecahan masalah yang semakin popular untuk digunakan dan menjadi salah satu cara pandang yang berbeda dari model pendekatan utama Artificial Intelligent yang lain.. Model pendekatan Case-Based Reasoning (CBR) dalam melakukan proses perhitungan kemiripan dalam menyelesaikan suatu masalah. Beberapa penelitian yang menerapkan CBR yaitu misalnya [9] menerapkan CBR untuk proses seleksi beasiswa. Selain itu [10] menerapkan CBR untuk penentuan status gunung berapi.

\section{METODE PENELITIAN}

\section{1 Case Based Reasoning}

Penalaran berbasis kasus atau yang lebih dikenal dengan case-based reasoning cara kerjanya dengan memanfaatkan data lama untuk proses memberikan rekomendasi. Proses dari CBR sebagaimana ditunjukkan pada Gambar 1 [11].

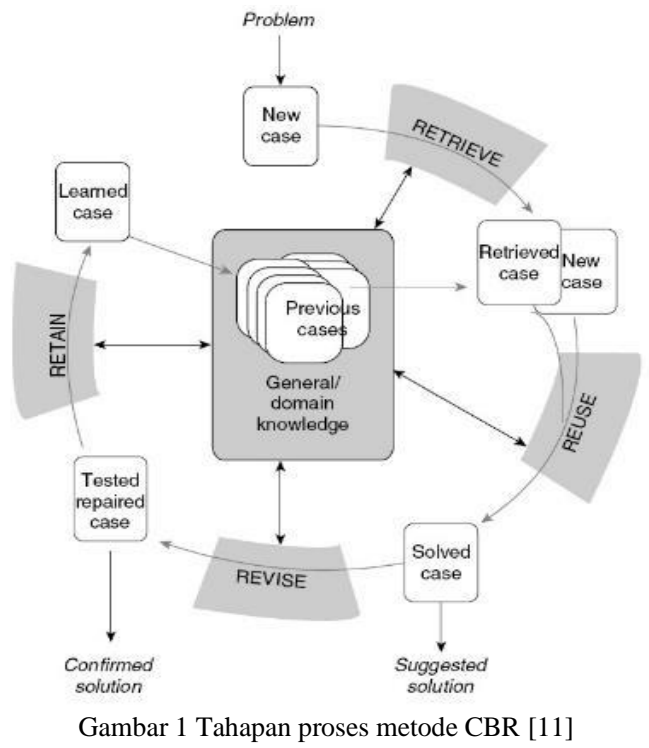

\section{a. Proses Retrieve}

Proses Retrieve yaitu proses menemukan lagi masalah atau kasus yang tingkat kemiripannya paling tinngi. Proses ini diawali dengan mengidentifikasi beberapa masalah yang ada, dimana identifikasi dilakukan dengan proses pencarian informasi, identifikasi kemiripan dan selanjutnya memilih masalah yang paling tinggi tingkat kemiripannya.

b. Proses Reuse

Proses Reuse adalah proses menggunakan kembali informasi atau pengetahuan yang telah ditemukan dari kasus yang pernah terjadi. Pada proses ini, penggunaan informasi yang ditemukan untuk masalah yang baru diperuntukkan terhadap 2 faktor yaitu: 1). Disimilaritas antara masalah yang pernah terjadi dan masalah yang ada pada saat ini. 2). Komponen apa yang ada pada masalah yang sebelumnya, dapat dipindahkan kemasalah yang baru. Sehingga, dalam pada proses ini dilakukan perhitungan secara matematis untuk mendapatkan tingkat kemiripan masalah yang terjadi sebelumnya dan yang baru.

Penghitungan dilakukan dengan menggunakan Persamaan 1.

Similarity $=\frac{S 1 * W 1+S 2 * W 2+\cdots+S n * W n}{S 1+W 2+\ldots+W n}$

\section{Keterangan:}

Similiarity = Similarity masalah baru terhadap masalah lama ( 1 jika sama dan 0 jika tidak)

$\mathrm{W}=$ Nilai bobot pada masalah baru

c. Proses Revise

Proses Revise adalah proses untuk mempertimbangkan dan menyempurnakan solusi yang diusulkan. Hal ini dilakukan ketika solusi yang direkomendasikan tidak sesuai dengan fakta-fakta dari kasus.

d. Proses Retain

Proses Retain adalah proses merekam untuk mencadangkan elemen - elemen dari keseluruhan proses yang terjadi yang memungkinkan untuk dimanfaatkan dikemudian hari. Proses ini memuat tentang informasi apa dari masalah yang ada untuk direkam, dalam bentuk apa, kemudian bagaimana cara menyusun masalah yang ada sehingga dikemudian hari mudah untuk memilih masalah yang tinggi tingkat kemiripannya.[6]

Pembangunan aplikasi berbasis web pernah dilakukan oleh [7] dengan implementasi Bahasa pemrograman PHP dan basisdata MySQL yang menghasilkan aplikasi sekolah berbasis web dan juga dilakukan oleh [10] yaitu implementasi CBR untuk aplikasi berbasis web yang menghasilkan aplikasi untuk diagnosis penyakit hepatitis.

\section{2 Metode pengembangan perangkat lunak}

Metode pengembangan perangkat lunak yang digunakan pada penelitian ini adalah metode prototype. Proses yang terjadi pada metode prototype adalah proses yang berulang dan memiliki siklus, dimana setiap siklus dapat menyelesaikan beberapa kebutuhan yang menjadi modul - modul yang dikembangkan oleh pengembang aplikasi. Siklus tersebut akan selalu berulang sampai prototype ini dapat diterima sesuai kebutuhan. Siklus ini dapat dilihat seperti digambar 2 . 


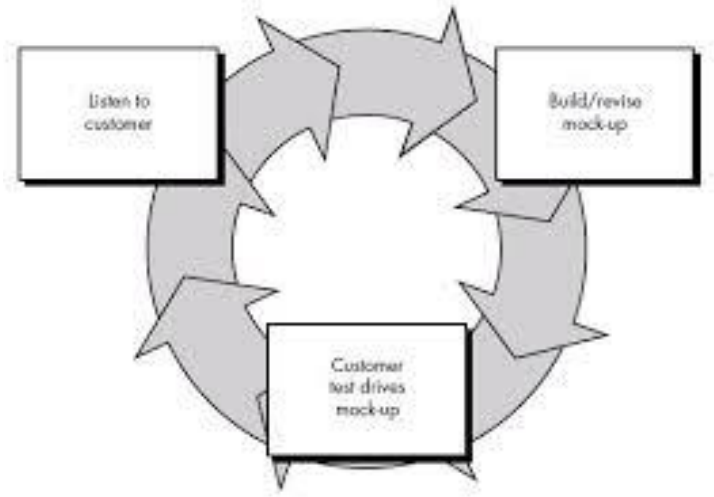

Gambar 2 Metode Prototype [8]

Metode prototype digunakan pada penelitian ini karena pada metode ini antara pengguna dan pengembang (peneliti) secara bersama terlibat dalam pengembangan aplikasi, sehingga komunikasi untuk memecahkan masalah pengembangan aplikasi dapat dipikirkan secara bersama dan berulang. Hal ini memungkinkan untuk menghasilkan aplikasi yang sesuai dengan kebutuhan dan bisa berjalan dengan baik. Pada metode prototype ada 3 tahapan proses secara garis besar yang dilakukan yaitu:

1. Listen to customer yaitu tahapan untuk proses pengumpulan data atau kebutuhan aplikasi. Pada tahapan ini antara pengguna dan peneliti secara bersama menemukan inti masalah pengembangan aplikasi dan mendefinisikan kebutuhan - kebutuhan apa saja yang seharusnya ada terkait dengan pengembangan aplikasi.

2. Build/revise mock-up yaitu tahapan untuk merancang prototype modul aplikasi sesuai dengan hasil definisi kebutuhan pada tahapan sebelumnya, kemudian selanjutnya implementasi pemrograman rancangan sehingga bagian modul yang telah didefenisikan selesai dan dilanjutkan ke tahapan selanjutnya, yaitu pengujian. Pada tahapan ini juga dilakukan proses updating dan perbaikan prototype yang telah dibuat sebelumnya yang telah melalui proses pengujian.

3. Customer test drives mock-up yaitu tahapan untuk menguji prototype aplikasi yang telah dibuat dan diupdate pada tahapan sebelumnya. Pengguna dan peneliti menguji prototype bersama untuk mencapai kesepakatan dan menghasilkan feedback pengujian untuk dijadikan bahan perbaikan prototype selanjutnya

\section{3 Pengumpulan Data}

1. Teknik Wawancara
Wawancara dilakukan untuk mendapatkan data dan informasi yang terkait dengan penelitian seperti yang dilakukan pada tahpan pertama metode prototype. Wawancara juga dilakukan secara langsung dengan beberapa stakeholder yang terkait dengan penelitian untuk mendapatkan data tentang hama, gejala, kasus yang pernah dan sering terjadi serta cara untuk menanggulanginya.

\section{Studi Pustaka}

Studi pustaka dilakukan untuk mencari literatur yang terkait dengan penelitian, baik melalui buku, hasil - hasil penelitian sebelumnya berupa paper jurnal. Literatur yang terkait yang akan dikumpulkan akan banyak membahas tentang hama, pestisida, algoritma Case Based Reasoning (CBR) dan tanaman padi.

\section{HASIL DAN PEMBAHASAN}

\section{1 Pemodelan Sistem}

Pemodelan sistem adalah suatu kegiatan membuat desain teknis berdasarkan evaluasi yang telah dilakukan pada kegiatan analisis.

\section{Diagram Usecase}

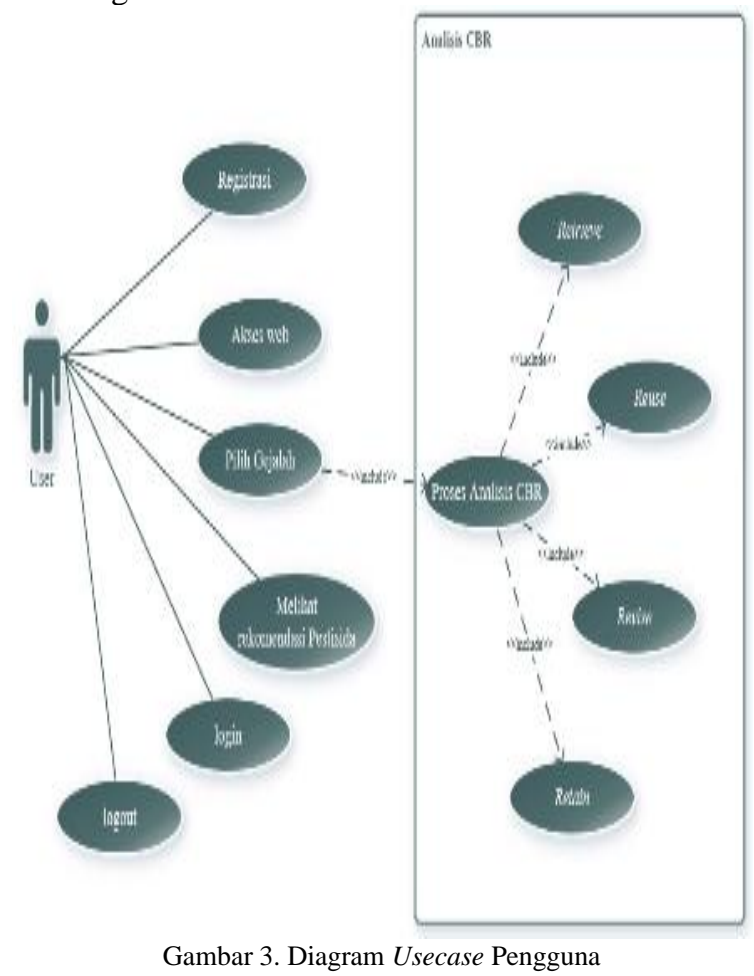

Gambar 3 menunjukkan bahwa pengguna dapat melakukan registrasi kemudian login untuk dapat menggunakan fasilitas yang ada pada aplikasi yang ditujukan untuk user. Setelah user login, maka user dapat menggunakan fasilitas untuk analisis pestisida yang telah dibuat dengan implementasi algoritma CBR, yaitu dengan memilih gejalah pada modul analisis CBR. User input gejalah dengan cara memilih gejalah yang muncul sesuai dengan yang dialami oleh user dan kemudian sistem akan 
melakukan proses analisis secara otomatis dan mencetak ke layar hasil rekomendasi pestisida yang dapat dilihat oleh user sesuai dengan gejalah yang telah diinput sebelumnya.

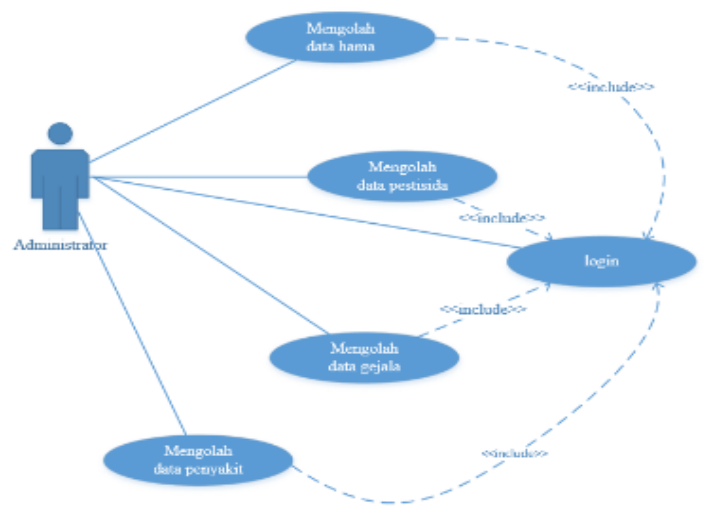

Gambar 4. Usecase Diagram Admininstrator

Gambar 4 menunjukkan apa yang dapat dilakukan oleh administrator aplikasi. Administrator aplikasi dapat mengolah data hama, mengolah data pestisida dan mengolah data gejalah. Mengolah yang dimaksud dalam hal ini yaitu menyangkut 4 proses yaitu: create, read, update, delete (CRUD)

2. Diagram Activity

a. Diagram Activity Admininstrator

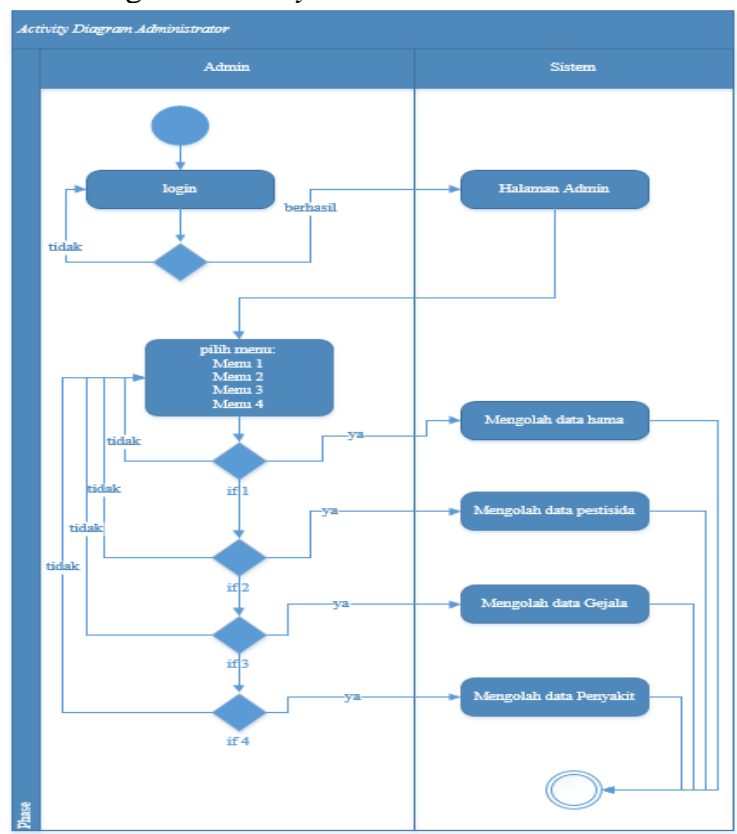

Gambar 5. Diagram Activity Admininstrator

Gambar 5 menunjukkan diagram aktivitas administrator dalam mengolah sistem, dimulai dari admin melakukan login yang kemudian sistem menjalankan proses validasi data, yang mana jika data ditemukan di basisdata, maka sistem akan melanjutkan untuk menampilkan halaman utama administrator aplikasi, namun jika gagal maka akan diarahkan kehalaman login. Apabila proses login berhasil, maka sistem akan menampilkan halaman utama administrator, kemudian administrator akan memilih menu apa yang akan diproses. Jika administrator memilih menu 1 maka sistem akan menampilkan halaman untuk mengolah data hama dan seperti itulah proses yang terjadi pada menu yang lain sampai administrator selesai.

\section{2 Diagram Activity pengguna}

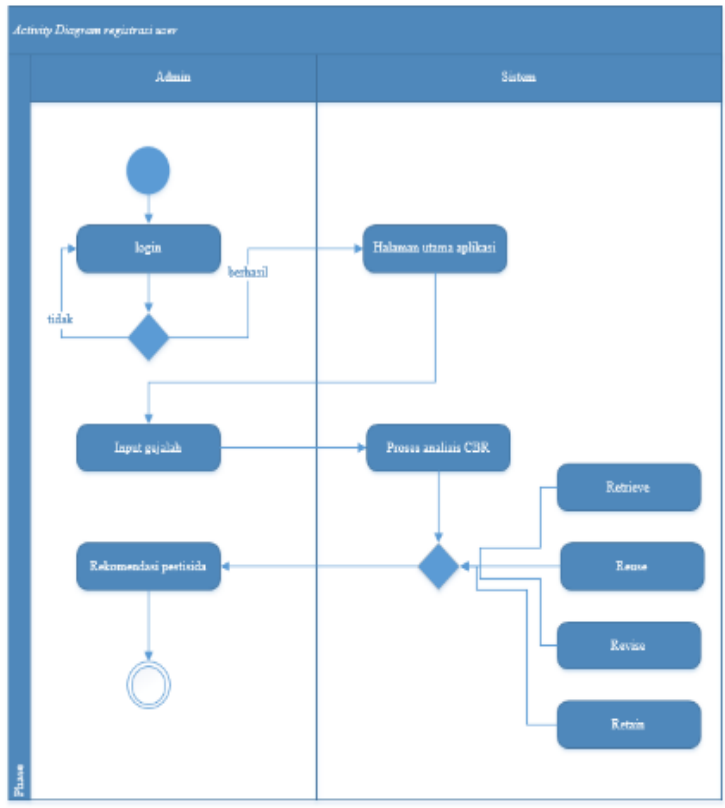

Gambar 6. Diagram Activity pengguna

Pada gambar 6 di atas menunjukkan proses aktivitas yang terjadi oleh user. Proses tersebut dimulai dengan user mengakses aplikasi kemudian mucul halaman login. User memasukkan username dan password kemudian sistem proses verifikasi data yang diinput. Jika data yang diinput ditemukan di basisdata, maka sistem akan melanjutkan menampilkan halaman utama aplikasi, namun jika tidak ditemukan, maka sistem akan menampilkan halaman login. Setelah user berhasil mengakses halaman utama aplikasi, maka user dapat menggunakan fasilitas untuk analisis pestisida dengan memilih menu analisis. Pada menu analisis akan muncul kumpulan gejala yang akan dipilih oleh user sesuai dengan kasus yang dialami oleh masing masing user. Setelah memilih serangkaian gejala yang sesuai maka sistem akan melakukan proses analisis menggunakan metode CBR yang telah diimplementasikan. Setelah selesai proses Analisa oleh sistem, maka sistem akan mengirimkan umpan balik ke user melalui tampilan di layar berupa rekomendasi beberapa pestisida yang cocok digunakan untuk kasus masing - masing user.

\section{3 Implementasi sistem}

a. Halaman Login

Sebelum user mendapatkan hak akses pada aplikasi Case Based Reasoning untuk rekomendasi 
pestisida maka terlebih dahulu pengguna memasukan username dan password.

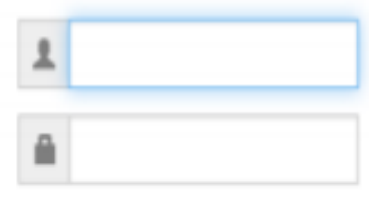

\section{Login}

Gambar 7. Halaman Login

b. Menu pengolahan data hama

Aplikasi ini dilengkapi juga dengan menu untuk mengolah data hama. Sebagaimana ditunjukkan pada Gambar 8 .

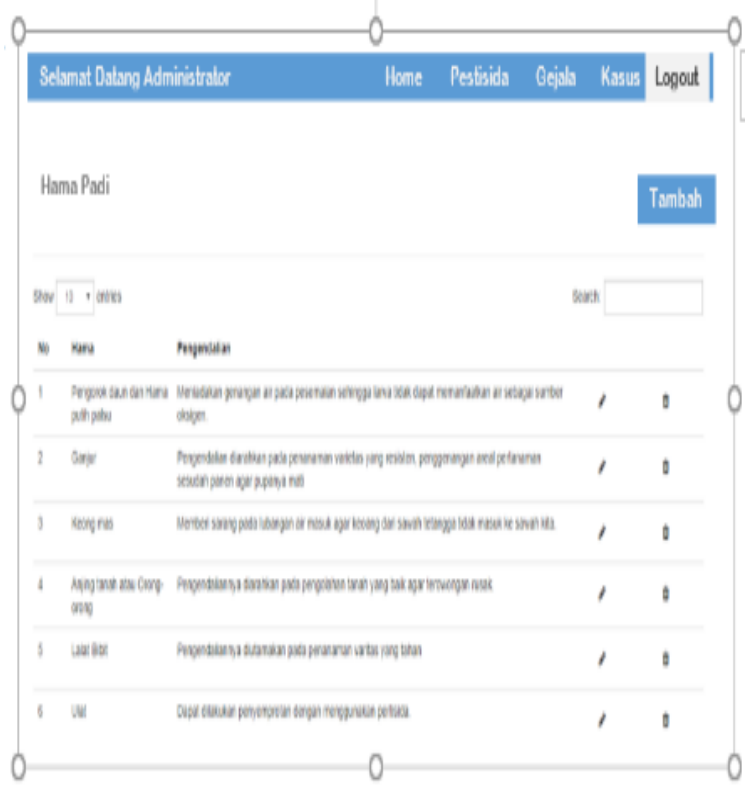

Gambar 8. Halaman menu data hama

\section{c. Menu pengolahan data Pestisida}

Rekomendasi atau output dari aplikasi ini adalah berupa rekomendasi pestisida, sebagaimana tujuan dari penelitian ini dengan menerapkan metode case based reasoning, hanya saja dalam penelitian tidak dilakukan pengujian akurasi. Terbatas hanya memberikan rekomendasi untuk membeli pestisida yang dilakukan oleh petani agar dapat membasmi hama saat hama menyerang padi mereka. sehingga pengolahan data pestisida sangat penting diterapkan dalam sistem agar dapat memudahkan pengguna dalam hal ini adalah petani. Hasil implementasi dari pengolahan data pestisida sebagaimana ditunjukkan pada Gambar 9.
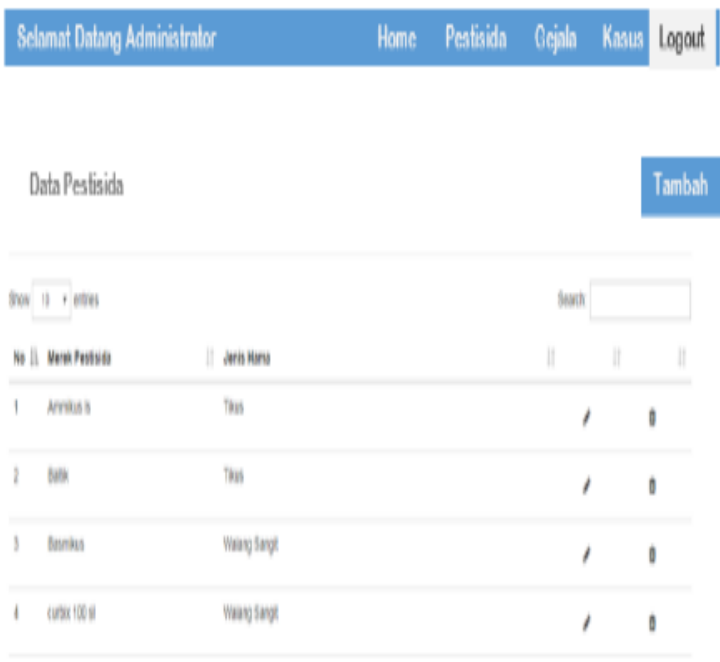

Gambar 9. Halaman menu data pestisida

\section{4 Pengujian}

Pengujian dilakukan untuk menguji fitur dan fungsi - fungsi sistem menggunakan metode pengujian blackbox. Metode pengujian blackbox digunakan untuk memastikan keseluruhan fungsi yang ada dalam sistem berjalan dengan semestinya. Dan hasil pengujian menunjukkan seluruh fungsi telah berjalan sesuai. Selain untuk menguji fungsi sistem, juga telah dilakukan uji manual hitungan algortima CBR, untuk memastikan implementasi CBR di sistem sudah berjalan sesuai dengan yang direncanakan.

\section{KESIMPULAN}

Implementasi algoritma Case-Based Reasoning $(C B R)$ telah berhasil dilakukan dan menjadi aplikasi berbasis web. Aplikasi berbasis web dibangun menggunakan model pengembangan prototype dan implementasi rancangan menggunakan bahasa pemrograman server side dan manajemen basisdata yang mendukung basisdata berbasis server. Berdasarkan hasil pengujian yang telah dilakukan, bahwa implementasi algoritma Case-Based Reasoning (CBR) untuk kasus pemilihan pestisida berbasis web dapat dilakukan dengan baik. aplikasi yang dibangun dapat memberikan hasil yang sesuai dengan perancangan dan dapat membantu user dalam memilih pestisida yang sesuai dengan kasus masing masing user. Namun pada aplikasi belum dilakukan pengujian akurasi sehingga penting kedepan untuk dilakukan pengujian akurasi dalam memberikan rekomendasi pestisida

\section{DAFTAR PUSTAKA}

[1] A. Amrullah., D. Sopandie., Sugianta dan A. Junaedi., 2014, "Peningkatan Produktivitas Tanaman Padi (Oryza sativa L.) melalui 
Pemberian Nano Silika”. PANGAN, Vol. 23 No. 1 Maret $2014: 17$ - 32 .

[2] Suhartono, 2014. "Dampak Pestisida Terhadap Kesehatan". Universitas Dipenogoro Kampus Undip.

[3] L. T. Sianturi., F. B. Manurung., C. Sitinjak dan D. S. L. Siantar., 2018, "Sistem Pendukung Keputusan Pemilihan Pestisida Dalam Mencegah Hama Padi Dengan Menggunakan Metode WASPAS". Prosiding Seminar Nasional Sains \& Teknologi Informasi (SENSASI).

[4] Kementerian Pertanian, 2011, "Peraturan Menteri Pertanian Nomor: 24/Permentan/SR.140/4/2011 Tentang Syarat Dan Tatacara Pendaftaran Pestisida". Jakarta

[5] M. Salmin dan S. Hartati. 2018, "Case Based Reasoning untuk Diagnosis Penyakit Infeksi Saluran Pernapasan Akut”. JIKO (Jurnal Informatika dan Komputer). Vol. 1(1), pp. 2126

[6] A. S. Soroto., A. Fuad., S. Lutfi., 2018, "Penerapan Metode Case Based Reasoning (Cbr) Untuk Sistem Penentuan Status Gunung Gamalama”. JIKO (Jurnal Informatika dan Komputer) Vol.1 (2). pp. 70-75
[7] A. Mubarak., 2019. "Rancang Bangun Aplikasi WEB Sekolah Menggunakan UML (Unified Modeling Language) dan Bahasa Pemograman PHP (PHP Hypertext Preprocessor) Berorientasi Objek". JIKO (Jurnal Informatika dan Komputer), vol. 2 (1), pp.19-25

[8] A. J. Mustafa., A. Mubarak dan R. Rosihan., 2018. "Sistem Informasi Geografis pencarian Lokasi Bank dan ATM di Kota Ternate"., JIKO (Jurnal Informatika dan Komputer), vol. 1 (2), pp. $48-55$

[9] F. Tempola dan S. D. Abdullah., 2018. "CaseBased Reasoning (CBR) untuk Penentuan Kelayakan Mahasiswa Penerima Beasiswa", Jurnal Protek. vol. 5 (2), pp.1-5.

[10] F. Tempola dan S. D. Abdullah., 2018. "Combination of case-based reasoning and nearest neighbour for recommendation of volcano status"., Prosiding International Conferences on Information Technology, Information Systems and Electrical Engineering (ICITISEE). pp.347-351. ISSN. 978-1-53860657-5

[11] A. Aamodt dan E. Plaza, 1994. "Case-Based Reasoning: Foundation Issues Methodological Variations, and System Approaches", AI Communication IOS Press, vol 7. pp. 39-59. 